\title{
Bone Cements and Their Potential Use in a Mandibular Endoprosthesis
}

\author{
Kok Weng Lye, B.D.S., M.D.S., ${ }^{1}$ Henk Tideman, M.D., D.D.S., Ph.D., \\ Matthias A.W. Merkx, M.D., D.M.D., Ph.D., ${ }^{2}$ and John A. Jansen, D.D.S., Ph.D. ${ }^{3}$
}

Bone cement was first used in the 1950s. Since then many modifications have been made and alternatives developed to the original polymethylmethacrylate (PMMA) cement. In view of the use of bone cement in a novel mandibular endoprosthetic system, we performed a review of the current literature on this material. Different cements are described and their potential use in a mandibular endoprosthetic system discussed. The PMMAbased cements are currently the most suitable choice. Plain PMMA has the longest track record and is the default choice for the initial development phase of this system. If there is a significant risk of infection, then an antibioticloaded PMMA cement can be selected. However, modified PMMA cements, composite resin cements, osteoinductive calcium phosphate compounds, and cementless fixation are options that offer advantages over PMMA cements, and further research should be conducted to study their suitability.

\section{Introduction}

$\mathbf{P}$ OLYMETHYLMETHACRYLATE (PMMA) WAS FIRST USED as bone cement in the 1950s when Sir John Charnley of the University of Manchester successfully adapted it for the cementation of an orthopedic prosthesis in a long bone. ${ }^{1}$ This event revolutionized the treatment of joint disease. Since then millions of cemented limb prostheses have been performed, and the medical literature has documented their phenomenal success.

However, cemented endoprostheses also have their share of problems, as failure does occur and has been postulated to be due to the PMMA cement. Infection and aseptic loosening of the prosthesis are the most common complications that necessitate prosthesis removal. As a result, there are concerns regarding the shortcomings of PMMA cement, and research into biologically superior cements over the last few decades has led to the creation of other bone cements such as the modified PMMA cements, calcium phosphate cements (CPCs), glass-ionomer cements (GICs), and composite resin cements (CRCs). Another research direction has led to the creation of cementless arthroplasty, which is also widely used and has shown considerable success. Yet another prospective solution is the creation of an osteoinductive cement that would have superior healing capability and bony integration.

All these advances have occurred mainly in the orthopedic arena, and the application of bone cement in the field of craniofacial surgery has been only for defect contour augmen- tation. Recently, however, there has been interest in using bone cement for endoprosthetic replacement of the mandible. ${ }^{2}$ Significant mandibular defects may result from extensive trauma, severe osteomyelitis, and ablative surgery for cancers of the head and neck. These result in high morbidity, with mastication, speech, and facial aesthetics being severely compromised without appropriate reconstruction. The aims of such mandibular reconstructions are to reestablish form and function. This can be accomplished by anatomical restoration of facial contours and framework and muscle reattachments. Currently, there are several reconstruction techniques available for the treatment of the discontinuity defect of the mandible, such as reconstruction plates, autogenous bone graft in customized trays, ${ }^{3}$ or microvascularized bone flaps. ${ }^{4,5}$ The disadvantages of the current techniques are donor site morbidity, ${ }^{6}$ infection, and failure of the bone graft. Most efforts have focused on replacing the defects with vital bone and tissues. This approach has an element of unpredictability as there are many variables involved and various complications often occur. ${ }^{7}$ The age of the patients, medical problems, local healing potential, and source of bone graft are all factors that make every case different and therefore less predictable. As a result, other approaches are being explored. In the field of tissue engineering, only two documented examples of using an engineered bone transplant to reconstruct the mandible and maxilla have been published. ${ }^{8-10}$ This method of reconstruction requires a period of implantation for scaffold maturation in separate site and microsurgical

${ }^{1}$ Department of Oral and Maxillofacial Surgery, National Dental Centre, Singapore, Singapore.

Departments of ${ }^{2}$ Oral and Maxillofacial Surgery and ${ }^{3}$ Periodontology and Biomaterials, Radboud University Nijmegen Medical Center, Nijmegen, The Netherlands. 
transplantation after the maturation. Tissue engineering using customized bone transplants will be the ideal solution, but its routine clinical applications will not be available in the near future. Therefore, the concept of an endoprosthetic modular reconstruction of the mandible is a potentially viable option that may eliminate the current problems faced by the other techniques as such a device will be easily available and cost effective. $^{2}$ This novel approach follows the modular endoprosthetic reconstruction concept that has been routinely used in limb-sparing surgery over the last two decades. ${ }^{11}$ This technique involves the removal of all diseased bone and the replacement of the missing portion of bone with an artificial device fixated within the remaining bone. The modular system combines standardized units to allow simplicity and flexibility in the reconstruction of defects of various sizes. The endoprosthesis equates to fixation of the prosthesis via cementation of an appropriate stem into the cancellous and marrow space of the host bone (Figs. 1-3). The choice of cement for the novel system is vital for its success as it has to provide the mechanical properties to allow the cement to act as a grout for the transfer of forces and have good biocompatibility with both bone, dental and nerve tissues found in the mandible. The cement also needs to exist in the in vivo environment for long periods of time without degradation. Among the many studies in the bone cement literature, none covers the whole range of available materials. This review article examines and presents an overview of the various types of bone cements currently obtainable followed by a discussion of their potential use in this new approach as well as the prospective usage of tissue engineering techniques to develop new cements that can overcome the weaknesses of the current materials.

\section{Plain PMMA Cement}

Following Chanley's success in using plain PMMA in total joint replacements, the cement was used in other applications, such as fracture fixation, tumor surgery, and percutaneous vertebroplasty. The widespread acceptance of the cement is a result of its simplicity of manipulation, low cost,

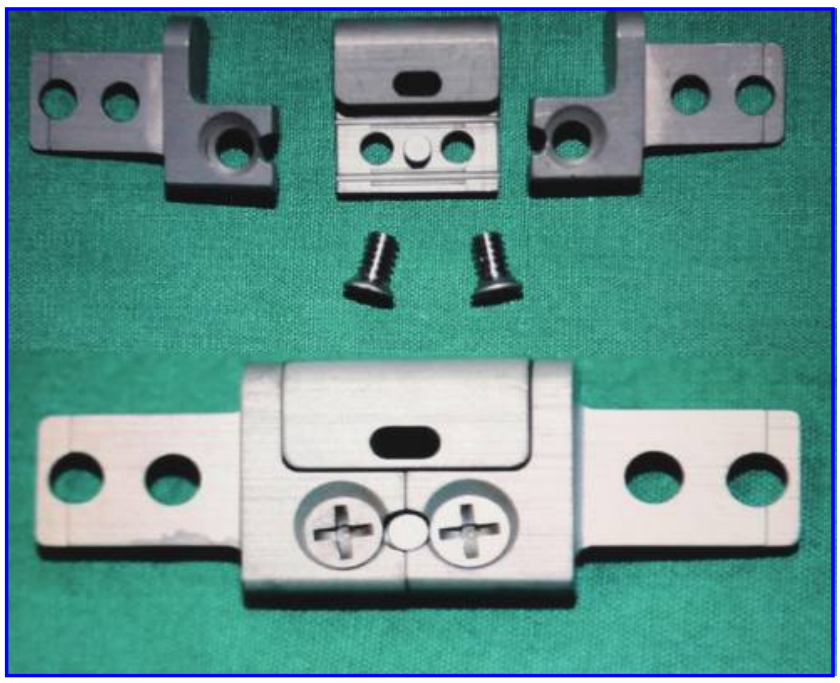

FIG. 1. Modular mandibular endoprosthesis-apart (above) and assembled (below). Color images available online at www.liebertonline.com/ten.

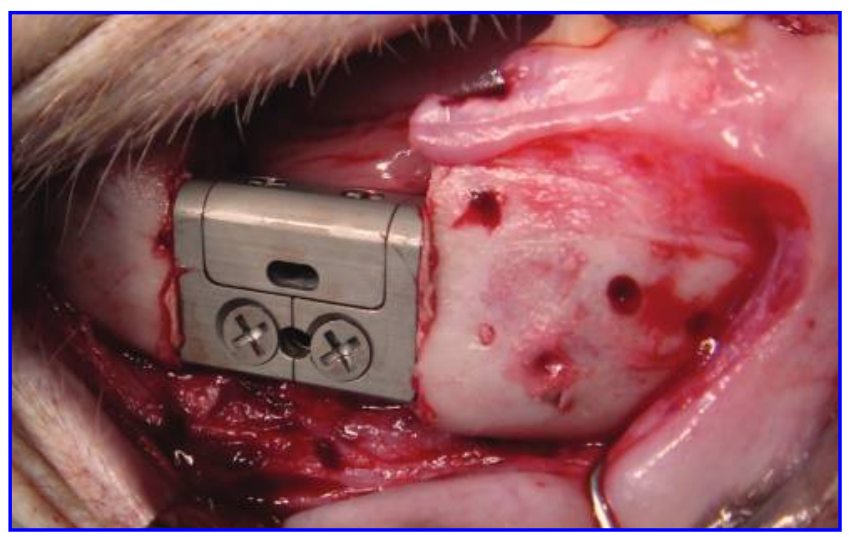

FIG. 2. Fixation and assembly of the endoprosthesis after $2 \mathrm{~cm}$ segmental resection of the body of mandible. Color images available online at www.liebertonline.com/ten.

good physical strength, and ready availability. There has been a consistently high tolerance to the material, and the survival of cemented prostheses in the hip and knee using PMMA bone cements is more than $90 \%$ after 15 years. ${ }^{12,13}$

More than 30 brands of plain PMMA cement are commercially available and approved by the relevant regulatory authorities of the United States and the United Kingdom. They are similar in composition ${ }^{14}$ and include two components, a powder and liquid, which are mixed together to create the final cement. The powder portion comprises prepolymerized PMMA or a PMMA-based polymer, a radiopacifier of barium sulphate or zirconium oxide particles and an initiator of benzoyl peroxide. The liquid portion comprises methyl methacrylate monomer, $N, N$-dimethyl- $p$-toluidine, as an accelerator and hydroquinone as an inhibitor of the polymerization reaction.

The mechanical characteristics of PMMA bone cement around a cemented prosthesis allow the cement to evenly distribute the stresses and loads from the prosthesis to the bone. The mechanical requirements for these systems are known and all plain PMMA cements currently marketed meet the main requirements of compressive strength $>70 \mathrm{MPa}$, tensile

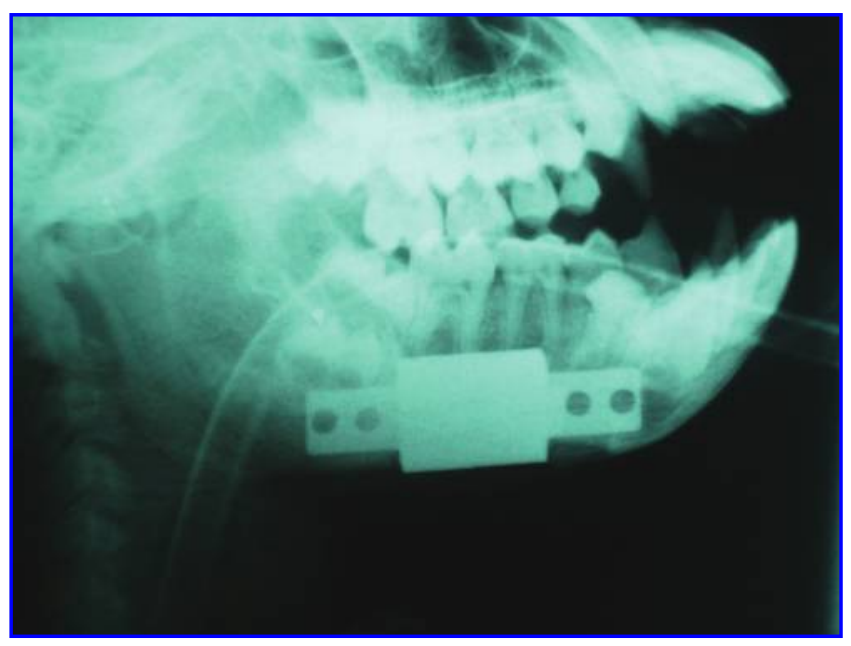

FIG. 3. Radiograph of modular mandibular endoprosthesis. Color images available online at www.liebertonline.com/ten. 
strength $>50 \mathrm{MPa}$, bending strength $>50 \mathrm{MPa}$, and modulus of elasticity $>1800 \mathrm{MPa} .{ }^{14}$ There are many other mechanical aspects to consider, and these are covered by technical publications that provide extensive descriptions of the mechanical properties of the cements and their evaluation ${ }^{15,16}$; however, it is out of the scope of this review to give further details.

Biologically, PMMA is considered to be inert and stable (Fig. 4). It is insoluble and does not degrade over time and function. PMMA was established very early on to have good biocompatibility. ${ }^{17,18}$

There are, however, several documented shortcomings of plain PMMA cement, which include: (1) lack of bioactivity and bonding between the cement and bone, which results in an intervening fibrous layer between the bone and PMMA, ${ }^{19}$ (2) thermal necrosis caused by a highly exothermic setting reaction, ${ }^{20,21}$ (3) chemical necrosis and tissue toxicity due to residual monomer and $N, N$-dimethyl- $p$-toluidine release, ${ }^{22}$ (4) a brittle material with insufficient fatigue resistance that is susceptible to failure when tensile forces are present, ${ }^{15}$ and (5) significant volumetric shrinkage of the cement during polymerization, which induces stresses and undermines the integrity of the cement-bone interface. ${ }^{23}$ The most common cause of arthroplasties failure is aseptic loosening, which accounts for almost two-thirds of the revision hip arthroplasties and one-half of the revision knee arthroplasties. ${ }^{24}$ Although, there is a multifactorial etiology for aseptic loosening, it has

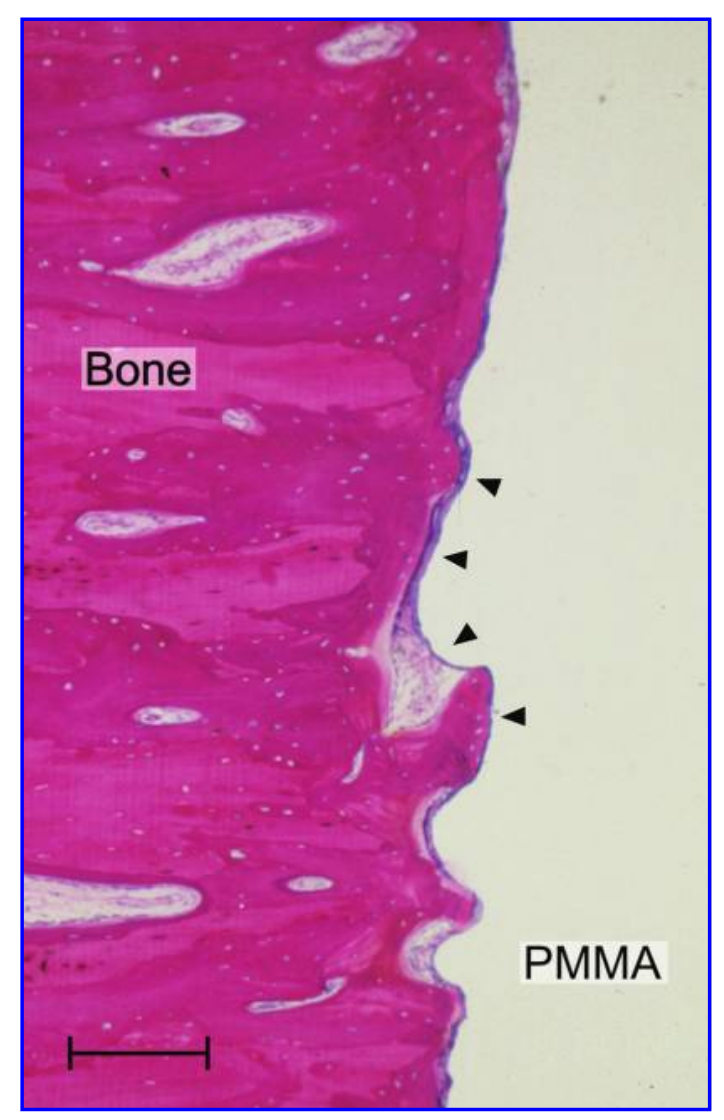

FIG. 4. Light micrograph showing polymethylmethacrylate (PMMA) installed in the cortical bone of a goat tibia showing PMMA being surrounded by a thin fibrous capsule. The Scale bar represents 200 micrometers. Color images available online at www.liebertonline.com/ten. been associated with the mechanical integrity and mechanical properties of the PMMA bone cement. An important parameter is the low impact and fatigue strength of the cement, which is especially crucial during functioning and continuous exposure to tensile stresses. It has been demonstrated under in vivo conditions that porosity is the major factor influencing the mechanical behavior of bone cement. ${ }^{25}$

The next step in the evolution of PMMA cement was the development of antibiotic-containing cements in 1969 by Buchholz ${ }^{26}$ on the basis that a deep infection following total joint replacement is a devastating complication for the patient. The diagnosis of a mild infection is difficult, ${ }^{27}$ isolation of the causative organism is problematic, ${ }^{28,29}$ systemic antibiotics are ineffective, ${ }^{30,31}$ and treatment usually requires multiple operations, with amputations and mortality sometimes unavoidable. ${ }^{32,33}$ The addition of antibiotics to a PMMA cement and their subsequent release enable a high concentration of antibiotics in the vicinity of the implant. ${ }^{34}$ Since their inception, antibiotic-loaded PMMA cements have become the standard of care in western Europe, including the United Kingdom and Scandinavia. There is good evidence of their efficacy and advantage over plain PMMA cements in reducing primary infections and improving the success rate in revision cases. ${ }^{35-37}$ Currently, in most parts of the world except the United States, these cements are used both prophylactically in primary arthroplasties and revision surgery.

Based on its pharmacological properties, gentamicin was the first and is still the most common antibiotic incorporated into bone cements. Studies have shown that the antibiotic is released at high concentrations during the early stage after implantation. One study found evidence of significant level of gentamicin level in the immediate surrounding tissue $(150 \mu \mathrm{g} / \mathrm{mL})$ up to 5.5 years after implantation. ${ }^{38}$ Other antibiotics less commonly used are tobramycin, vancomycin, fusidic acid, erythromycin with colistin and clindamycin. The addition of an antibiotic does affect the physical and mechanical properties of the cements, but they are still within the clinical requirements. ${ }^{14}$

Although the incorporation of antibiotics into bone cements has raised concerns about such issues as the induction of antimicrobial resistance, allergic reactions, toxic side effects, mechanical deterioration of the cement, and prolonged release of subtherapeutic levels of antibiotics, ${ }^{39}$ there is no evidence of any significant problem.

In summary, PMMA cement and its antibiotic-containing formulations are well established and the gold standard to which all other bone cements must be compared. They should be the default cements chosen for any new approach. The choice between a plain and an antibiotic-loaded PMMA is not so clear. There are different practices in different geographical regions. In the United States, antibiotic-loaded cements are cleared for use only in revision arthroplasties, ${ }^{37}$ whereas they are routinely used in primary arthroplasties in some European countries. Thus, the clinicians must consider the accepted practices of the region and the risk factors of individual patients before selection of the cement. There are some published guidelines on this matter. ${ }^{37}$

\section{Modified PMMA Cement}

Although PMMA has had wide acceptance and historical success as a prosthetic cementation material, its inherent 
problems have long been criticized. The principal reason for cemented arthroplasty revision is aseptic loosening after long-term implantation, which accounts for approximately $75 \%$ of all failed primary total hip joint replacements. ${ }^{40,41}$ The main mechanism is fatigue crack propagation in the cement, which initiates from "weak zones," that is, the bone-cement interface, cement-prosthesis interface, or the particles within the cement mantle, under cyclical loading. ${ }^{16,42}$ This mechanical failure then produces particles or debris that are phagocytized by macrophages, which in turn produce tumor necrosis factors that cause bone resorption and aseptic loosening. ${ }^{43}$ The main reason for this phenomenon is the lack of bioactivity of PMMA cement. ${ }^{44}$ Therefore, there is no bone-cement bonding and no direct transfer of forces from the cement to the bone. This issue has prompted the development of modified PMMA cement formulations.

Numerous approaches to improve PMMA cement have been proposed, and much research has been conducted, producing many modifications with good potential. Some published reviews have comprehensively described these strategies. ${ }^{45-47}$ Table 1 summarizes the different problems targeted and the solutions and approaches used to modify the cement. There are also many combinations of the different approaches to simultaneously solve multiple problems, which are based on the different applications of the cement and the characteristics desired for a particular purpose. The most popular modified PMMA cements in recent years are the alternative radiopacifier cements, bioactive cements, and hydrophilic, partially degradable and bioactive cements. ${ }^{45}$ However, formost of thesemodified cements, completeinformation about their optimum proportion, complex mechanical characteristics, biocompatibility, and long-term stability is unavailable. Hence, although this category of cements has much potential, presently there is no proof of their long-term success.

\section{Calcium Phosphate Cement}

Calcium phosphate cement is a blend of various calcium phosphate powders that form an apatite phase or brushite when they set. ${ }^{97} \mathrm{CPC}$ that forms hydroxyapatite (HA) during hardening is called apatite cement, and CPC that forms brushite during setting is called brushite cement. ${ }^{98}$ The original CPC formulation was developed by Brown and Chow (U.S. Patent No. 4,518,430). ${ }^{99}$ The setting of CPC is based on a dissolution-reprecipitation mechanism, which is induced by mixing calcium phosphate powders with a liquid phase. The precipitated crystals interlock to form a hard mass. $^{98}$ The advantages of CPC are the slow exothermic reaction and setting without shrinkage. In addition, its composition is similar to that of bone, and it possesses excellent bone biocompatibility (Fig. 5). The use of a bioactive material capable of releasing calcium and phosphate ions has the potential to promote osteoconduction. Studies show bone growth on the surface and into the pores of this material after implantation. ${ }^{100}$ As a result of its great potential as a grafting material, a large number of CPC formulations have been prepared and studied for possible clinical applications. In the field of dentistry, oral surgery, and craniofacial surgery, CPCs have been found to be useful grafting materials for periodontal, jaw, and craniofacial defects. ${ }^{101-104}$

All CPCs consist of a solid and a liquid component. The solid component consists of two or more calcium phosphate compounds, whereas the liquid component can be water, saline, or sodium phosphate. The combination of the two components in a specific proportion results in a phase transformation with the calcium phosphate dissolving and then precipitating into a less soluble calcium phosphate, which is determined by the $\mathrm{pH}$ of the cement setting reaction. ${ }^{105}$ Mechanically, CPCs have a compressive strength equal to or greater than bone, but a significantly lower tensile strength (1-10 MPa). Therefore, CPCs can be used only in non- to lowloadbearing applications, such as cranioplasty, facial contouring, and periodontal defects. Their use has also yielded good results in the fixation of bone fractures. ${ }^{106,107}$ A study that attempted to use CPC to fix titanium implants found that the material was biocompatible and osteoconductive, but that the load failure values when using CPC as a grout were significantly lower than those of PMMA. ${ }^{108}$ Numerous attempts have been made to improve CPCs via such methods as (1) optimization of osteoconduction through the creation of pores $^{109}$ (Fig. 6), (2) improvement of the strength of the cement through the incorporation of various fillers, ${ }^{110,111}$ and (3) applications for delivery of therapeutic molecules such as antibiotics, anti-cancer drugs, and anti-inflammatories. ${ }^{112,113}$ The few CPCs commercially available, Norian Skeletal Repair System $^{\circledR}$ (Synthes, Inc., West Chester, PA), BoneSource ${ }^{\circledR}$ $\left(\right.$ Stryker $^{\circledR}$, Kalamazoo, MI), and $\alpha$-Bone Substitute Material ${ }^{\circledR}$ (Etex Corporation, Cambridge, MA), are only recommended for nonweight-bearing applications.

CPC can also be used for the manufacturing of ceramic scaffolds with precise dimensions and predetermined structure. Currently, rapid prototyping techniques are used to make customized scaffolds. These methods are based on extrusion freeforming or fugitive wax molds, which is followed by a sintering process. ${ }^{114,115}$ The procedure makes use of an aqueous calcium phosphate slurry. Self-setting CPC can be used as replacement of the slurry, which would make the production process easier, as sintering of the scaffold is no longer required.

In summary, CPCs have been proven effective in clinical applications in nonload-bearing situations and maxillofacial and craniofacial surgery. Novel formulations with different modifications are actively being researched and improvements have been made in the mechanical and biological properties of this family of cements. Thus, in the not-too-distant future, a product may exist that can handle a load-bearing situation and confer all the other biological advantages of CPC. The tissue engineering approach utilizing calcium phosphatederived scaffolds with stem cells or osteoinductive proteins is a promising method in the future, but there are some important issues that need to be studied before this can occur.

\section{Calcium Sulfate Cement}

This cement, also known as gypsum or plaster of Paris, has been used extensively in dentistry and as a bone graft substitute in 1961 by Peltier. ${ }^{116}$ For its preparation, calcium sulfate powder is mixed with water, resulting in crystallization. This process is random and the final product contains many defects. Surgical-grade calcium sulfate cements (CSCs) involve the use of calcium sulfate hemihydrate. ${ }^{117}$ CSC inhibits fibrous tissue ingrowth and encourages angiogenesis and osteogenesis because of its mild acidic environment and gradual resorption. ${ }^{118}$ The resorption of the cement occurs via 
Table 1. Problems Targeted and Strategies to Improve Polymethylmethacrylate Cement

\begin{tabular}{|c|c|c|}
\hline Problem targeted & Category of cement & Approach used \\
\hline \multirow[t]{6}{*}{ Poor adhesion } & \multirow[t]{3}{*}{ Cross linked } & Add triethylene glycol dimethacrylate ${ }^{48,49}$ \\
\hline & & Add ethylene glycol dimethacrylate ${ }^{48,49}$ \\
\hline & & Add poly (ethylene glycol) dimethacrylate ${ }^{48,49}$ \\
\hline & Solid phase & Partial replacement of MMA by hydroxypropylmethacrylate ${ }^{50}$ \\
\hline & \multirow[t]{2}{*}{ Improved adhesion } & $\begin{array}{l}\text { Use tributyl borane and partially replace MMA with } \\
\text { 4-trimethacryloyloxyrthyl trimellitate }\end{array}$ \\
\hline & & Add 3-methacryloxyproyl-trimethoxysilane $e^{52}$ \\
\hline \multirow[t]{3}{*}{ Inert cement } & \multirow[t]{3}{*}{ Bioactive } & $\begin{array}{l}\text { Add hydroxyapatite } \mathrm{e}^{53} \text { /apatite wollastonite glass }{ }^{54} / \text { recombinant }^{56} \\
\text { human growth hormone }{ }^{55} / \text { hydroxyapatite }+ \text { chitosan }^{56}\end{array}$ \\
\hline & & $\begin{array}{l}\text { Add the above with an additional polymer (bispheno glycidyl } \\
\text { dimethacrylate }{ }^{57} / \text { PEMA }^{56} / \text { PEMA with } n \text {-butyl methacrylate } \\
\text { META-PMMA }^{59} / \text { methacrylic acid }^{60} / \text { diethyl aminoethyl } \\
\text { methacrylate }^{61} \text { ) }\end{array}$ \\
\hline & & $\begin{array}{l}\text { Add 3-methacryloxyproyl-trimethoxysilane/3-aminopropyltriethoxysilane/ } \\
\text { 3-glycidoxypropyltrimethoxysilane/soluble calcium salt }{ }^{62,63}\end{array}$ \\
\hline \multirow[t]{3}{*}{$\begin{array}{l}\text { Lack of } \\
\text { degradability }\end{array}$} & Partially degradable & $\begin{array}{l}\text { Use poly (hydroxyalkenoate)/poly (\{R\}-3-hydroxybutyrate)/ } \\
\text { PMMA-graft-poly (\{R\}-3-hydroxybutyrate) }\end{array}$ \\
\hline & \multirow[t]{2}{*}{ Biodegradable } & $\begin{array}{l}\text { Add cancellous bone } e^{66} / \text { nanosized } \mathrm{Al}_{2} \mathrm{O}_{3}{ }^{45} / \beta \text {-TCP } \\
\text { sodium fluoride }\end{array}$ \\
\hline & & $\begin{array}{l}\text { Add epoxy- } \mathrm{SiO}_{2}{ }^{71} / \text { micro- or nanosized } \mathrm{TiO}_{2}^{72} / \text { chitosan }^{56} \text { and an } \\
\text { additional polymer (bisphenol glycidyl dimethacrylate }+ \text { triethylene } \\
\text { glycol dimethacrylate }+\mathrm{MMA}^{71} / \mathrm{PEMA}^{45} / \mathrm{DEAEMA}^{61} \text { ) }\end{array}$ \\
\hline $\begin{array}{l}\text { Highly exothermic } \\
\text { reaction }\end{array}$ & Modified monomer & Add a comonomer that dissolves in $\mathrm{MMA}^{73}$ \\
\hline \multirow[t]{2}{*}{ High elastic modulus } & \multirow[t]{2}{*}{ Reduced modulus } & Use polybutyl methacrylate instead of PMMA ${ }^{45}$ \\
\hline & & Use PEMA with $n$-butyl methacrylate ${ }^{74}$ \\
\hline \multirow{3}{*}{$\begin{array}{l}\text { Low tensile strength, } \\
\text { fracture toughness, } \\
\text { and fatigue life }\end{array}$} & \multirow[t]{3}{*}{ Reinforced } & $\begin{array}{l}\text { Add fibers of graphite } 75 / \text { stainless steel }{ }^{76} / \text { titanium }^{77} / \text { Kevlar }^{(8)} 29^{78} / \\
\text { polyethylene }{ }^{79} / \text { ultrahigh-molecular weight polyethylene }^{80}\end{array}$ \\
\hline & & $\begin{array}{l}\text { Add particulates of rubber-toughened PMMA powder }{ }^{81} / \text { poly } \\
\text { (isobutylene) })^{82} / \text { acrylonitrile-butadiene-stryene } 83 / \text { poly }^{4} \\
\text { (caprolactone) }^{84} / \text { polybutyl methacrylate }^{45} / \text { alumina powder }^{85} / \\
\text { chitosan }^{86}\end{array}$ \\
\hline & & Add carbon nanotubes ${ }^{87}$ \\
\hline \multirow[t]{4}{*}{ Toxicity of DMPT } & Reduced DMPT & Reduce DMPT by $50 \%$ \\
\hline & Solution to solution & Two PMMAs predissolved in MMA solutions ${ }^{89}$ \\
\hline & Antioxidant & Add vitamin $\mathrm{E}^{90}$ \\
\hline & $\begin{array}{l}\text { Alternative } \\
\text { accelerator }\end{array}$ & $\begin{array}{l}\text { Use a higher molecular weight accelerator }{ }^{45} / \text { polymerizable tertiary }^{91} \text { amines } / \text { tertiary amine with long-chain fatty acid } \\
\text { a2 }\end{array}$ \\
\hline $\begin{array}{l}\text { Nonuniform dispersal } \\
\text { of barium sulphate } \\
\text { or zirconium oxide }\end{array}$ & $\begin{array}{l}\text { Uniformly dispersed } \\
\text { radiopacifier }\end{array}$ & Use nanosized barium sulphate ${ }^{45}$ \\
\hline \multirow{5}{*}{$\begin{array}{l}\text { Toxicity of } \\
\text { radiopacifier }\end{array}$} & \multirow{5}{*}{$\begin{array}{l}\text { Alternative } \\
\text { radiopacifier }\end{array}$} & Use a bromine-containing chemical ${ }^{45}$ \\
\hline & & Iodine-containing chemical ${ }^{93}$ \\
\hline & & Bismuth compound ${ }^{94}$ \\
\hline & & Tantulum powder ${ }^{95}$ \\
\hline & & Heavy metal-containing organic material ${ }^{96}$ \\
\hline
\end{tabular}

MMA, methylmethacrylate; PMMA, polyMMA; DMPT, $N, N$-dimethyl- $p$-toluidine; PEMA, polyethyl methacrylate; $\beta$-TCP, $\beta$ tricalcium phosphate.

dissolution and is complete in about 2 months. ${ }^{119}$ Studies have shown that CSC is bone biocompatible and comparable to autogenous bone in healing rate when used as a bone graft substitute and bone void filler in animal defect models. ${ }^{120}$ However, its very rapid resorption and low compressive strength are shortcomings that hamper the clinical application of CSC. ${ }^{121}$ Another innovation is the addition of an antibiotic in CSC, which makes it effective in the treatment of acute bone infections associated with bone loss. Mechanically, a commercial CSC formulation (MIIG ${ }^{\circledR} \mathrm{X} 3$; Wright Medical Technology,
Arlington, TN) has been reported to achieve a reasonable compressive $(\sim 96 \mathrm{MPa})$ and tensile $(\sim 16 \mathrm{MPa})$ strength. $^{122}$

CSC has shown good promise as a bone defect filler and bone substitute, with good biocompatibility and resorptive capability to allow bony ingrowth and replacement. However, the mechanical properties of the cement do not measure up in load-bearing situations. Further, the cement frequently undergoes too rapid a rate of resorption, which means insufficient bony ingrowth and replacement, early loosening of the cemented prosthesis and therefore, failure. 


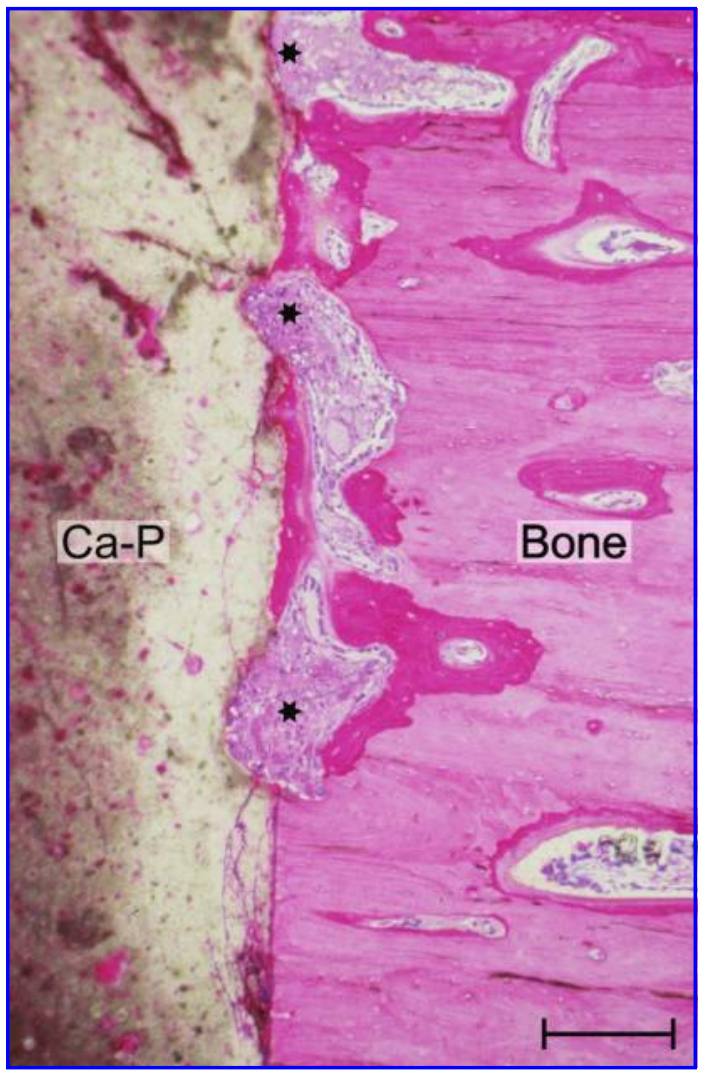

FIG. 5. Calcium phosphate cement installed in the cortical bone of the tibia of a goat. At the cement-bone interface, new bone was deposited. In addition, degradation of the cement can be observed, which was due to cellular activity. The scale bar represents 200 micrometers. *Remodeling lacuna. Color images available online at www.liebertonline.com/ten.

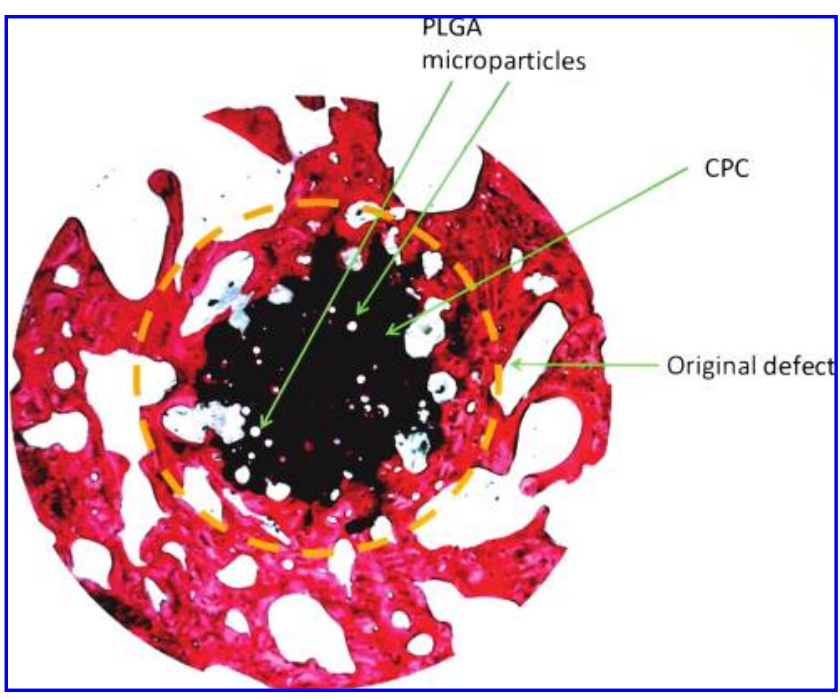

FIG. 6. Light microgram showing injectable calcium phosphate cement (CPC) provided with poly(lactic-co-glycolic acid) (PLGA) microparticles, 4 weeks after implantation degradation of the microparticles occurred associated with the ingrowth of new bone and additional degradation of the calcium phosphate cement. Color images available online at www.liebertonline.com/ten.

\section{Glass-Ionomer Cement}

GIC, also known as polyalkenoate cement, was originally developed as a dental restorative material. It has been very successful as it is highly biocompatible and shows beneficial properties, such as adhesion to tooth structure and release of fluoride ions, which confers resistance to caries. As a result, the development of GIC for medical usage has been suggested. ${ }^{123}$ Interest in medical applications of GIC has been generated for it possesses unique properties that give it advantages over PMMA cement.

The setting reaction of GIC occurs through the transfer of ions from the glass to the matrix. This reaction is not exothermic, which eliminates the risk of thermal damage to the surrounding tissue and also allows the cement to be a drug delivery system through the provision of temperaturesensitive drugs. Second, GIC does not have any volumetric shrinkage on setting. Third, this cement is able to bond to bone and metals, which means that there is chemical bonding in addition to the normal mechanical interaction on which PMMA relies. Last, the cement exhibits osteoconductive properties after implantation in bone, in contrast to bioinert plain PMMA.

However, the mechanical properties of GIC have proven to be adequate only for low to moderate load-bearing applications. In addition, more recent studies that have focused on the biocompatibility of GIC have reported in vitro toxicity reactions that have been linked to fluoride ion release, the release of aluminum from the cement, and the low $\mathrm{pH}$ of the cement during setting and maturation. ${ }^{124}$ In vivo studies have yielded better results, with extensive bone formation on the GIC surface. Studies have also reported adverse effects of GICs on nerve function, ${ }^{125,126}$ which contraindicates the use of GICs in situations with exposed nerves and neural tissues. Unfortunately, this effect was unknown to others, resulting in four cases of post-otoneurosurgery aluminum encephalopathy ${ }^{127}$ and a case of facial nerve paralysis. ${ }^{128}$

Clinical use of the material has had mixed success. GIC has performed well in otorhinolarnygolical applications, but not when used as an allograft bone expander or in revision arthroplasty. Early reloosening has been found as well as aluminum in the surrounding bone. Therefore, it is concluded that the GICs currently available are not suitable in load-bearing situations. However, research has led to the improvement of the physical properties of GIC, with resinmodified versions, highly viscous cements, and the addition of filler particles such as HA. ${ }^{129,130}$

In view of these findings, no GIC currently exists that is suitable for cementation of an endoprosthetic system. The main concerns are the mechanical properties of the cement in load-bearing situations and possible biocompatibility issues, as there is an abundance of nerves and other highly specialized dental tissues in the region.

\section{Composite Resin Cement}

Dental composite resins are composed of a resin matrix that is mixed with other materials to produce properties superior to the individual components. The first particulatefilled composite was patented in 1951 by Knock and Glenn. ${ }^{131}$ This was further improved by Bowen, and a new resin, bisphenol glycidyl dimethacrylate (BIS-GMA), was 
patented in 1962, in which the silica filler particles were treated with vinylsilane to allow their chemical bonding to the resin matrix. ${ }^{132}$ This material was widely accepted as a dental restorative material and is the basis for the current composite resins of today.

A composite resin consists of four main components: an organic resin matrix, an inorganic filler, a coupling agent that creates bonding between the inorganic and organic components, and an initiator/accelerator, which results in the curing of the material. In modern dental composites, the resin matrix comprises BIS-GMA, urethane dimethacrylate, and triethylene glycol dimethacrylate. These components were developed to replace the methylmethacrylate in acrylic resin and boast several advantages, such as reduced polymerization shrinkage, quick setting, and superior hardness. This resin matrix is then highly reinforced with filler particles to give rigidity, increased tensile and compressive strength, decreased polymerization shrinkage, a decreased coefficient of thermal expansion, decreased water sorption, an increased modulus of elasticity, and abrasion resistance. Silicates and glasses of different sizes are used as filler particles.

Fiber-reinforced composites have been developed for bone fixation and load-bearing implants. ${ }^{133}$ Bone fixation devices made from fiber-reinforced composites have been shown to be well adapted to bone and offer stiffness and strength. ${ }^{133}$ Carbon fiber-reinforced composites also demonstrate good biocompatibility and have been found to perform well as intervertebral implants and bone fixation screws. Fixation plates made from this material can even rival their titanium counterparts. ${ }^{133}$ Other developments have produced different composites that are tailored for various applications in the area of orthopedic implants and bone-grafting materials.

As for cementation purposes, HA composite resin is a CRC that has been developed as an alternative to PMMA for the stabilization of fractures during cancellous screw fixation. ${ }^{134}$ The cements combine HA with three acrylic monomers, of BIS-GMA, 2,2 bis-(4-methacryloyloxyethoxyphenyl) propane, and triethylene glycol dimethacrylate. Studies have shown that HA CRC has high compressive strength, minimally exothermic polymerization, and good biocompatibility. ${ }^{134,135}$ CRCs used in vertebroplasty also demonstrate good mechanical properties, bioactivity, and direct bone apposition on the cement. ${ }^{136,137}$ One such commercially available product is Cortoss ${ }^{\circledR}$ (Orthovita Malvern, PA).

Although studies have shown the good biocompatibility of CRCs, there are controversial biological issues related to the composite materials. Bisphenol-A, a precursor of BISGMA, has been found to be estrogenic. ${ }^{138,139}$ Although BISGMA does not stimulate the progesterone receptors of breast cancer, there are reservations about long-term effects due to the chemical components that do leach out and accumulate in local and distant tissues. ${ }^{140,141}$

The literature has shown that CRCs are good potential candidates for the cementation of an endoprosthesis and have several advantages over conventional PMMA cement. However, the products of biodegradation from the cement and their by-products may have long-term effects on the surrounding tissues and organs. These effects occur especially when CRCs are applied in load-bearing situations, which can result in increased degradation of the cements because of stress and motion.

\section{Cementless Fixation}

In the 1970s, researchers assumed that premature loosening and failure of cemented prostheses were related to "cement disease."142,143 As a consequence, some investigators directed their research and development efforts toward prostheses that do not require any cementation. Cementless fixation was achieved by the application of surface-coated implants that provide initial stability and allow osseous ingrowth onto and into the prostheses. The biological fixation of the implant to the bone that is finally obtained allows the transmission of forces across the interface. ${ }^{144,145}$ There is growing interest in this method as it preserves bone stock and eliminates the use and disadvantages of cement.

The most frequently used approach to modify the bonebonding capacity of an endoprosthesis is the application of a calcium phosphate coating by plasma spraying.

Calcium phosphate coatings have been shown to be nontoxic, nonallergenic, and noninflammatory. ${ }^{146,147}$ These bioactive coatings encourage the growth and apposition of bone along the implant surface. ${ }^{148,149}$ Although meta-analysis shows that cemented total hip replacements still demonstrate better survival, uncemented implants are continuously improving with changes in their design. ${ }^{150}$ Comparative studies between cemented and uncemented fixation are still limited and provide only medium-term data (5-10 years). ${ }^{151,152}$ Long-term evaluation is required to determine whether cementless fixation offers any significant advantages with regards to prosthesis survival and revision complexity over cemented fixation.

Cementless fixation is a potentially viable option for the fixation of a mandibular endoprosthesis, but the design of the prosthesis is critical as the mandible has a varying curvature and cross-sectional area at different locations. The stem of the prosthesis needs to be customized to provide a precise fit and have a sufficiently large surface area to provide adequate immobilization during fixation and early function.

\section{Osteoinductive Bone Cements}

All the cements mentioned in the above sections are either inert or osteoconductive. However, the endoprosthetic system may be used in areas or tissues that are compromised, such as irradiated tissues after oncologic treatment. In these circumstances, osteoinductivity of the cement is desired as it can recruit the pluripotent cells from surrounding tissues and stimulate their differentiation into osteoprogenitor cells. ${ }^{153}$ This will promote the rate of bone healing in normal situations and improve the success in unfavourable regions. The phenomenon is shown by certain biomaterials that stimulate bone deposition even when placed in ectopic sites away from the skeleton, but the principle has been largely unexplainable. ${ }^{154,155}$

CPCs and ceramics have been reported to possess osteoinductive properties. ${ }^{154,156,157}$ They showed bone formation in the pores of porous calcium phosphate biomaterials. However, not all calcium phosphate compounds exhibit this behaviour. Pertinent studies concluded that the factors critical to the osteoinductivity of the biomaterials are as follows: (1) chemistry, (2) sintering temperature, (3) material dissolution, (4) three-dimensional topography, (5) microporosity, 
(6) macroprosity, and (7) the animal model studied. ${ }^{153,154}$ It is only when the biomaterial fulfills all the required criteria that bone induction will occur. There are also attempts to augment the osteoinductivity by incorporating bone morphogenetic proteins, which are well-recognized bone-inductive proteins, into the biomaterials. In animal studies, superior osteoinductivity has been shown when bone morphogenetic proteins are loaded onto the calcium phosphate biomaterials. ${ }^{158-161}$ Nevertheless, the creation of osteoinductive biomaterials still needs optimization and customization for each different application. For example, endoprosthesis cementation requires a material that shows structural integrity and mechanical strength primarily in addition to the osteoinductivity.

\section{Conclusions}

Several bone cements are available, but currently only PMMA-based cements are appropriate for use in the proposed mandibular endoprosthetic system. Plain PMMA has the longest track record and is still the default choice for the initial development phase of this therapy. If there is a significant risk of infection, then an antibiotic-loaded cement should be selected. However, modified PMMA cements, CRCs, and cementless fixation options have to be studied, and the creation of new osteoinductive cements that have favorable bone response, partial resorption with bone ingrowth, and stronger bone-cement bonding is important to ensure better success of the novel mandibular endoprosthetic system.

\section{Disclosure Statement}

The authors of this review article do not have any commercial associations that might create a conflict of interest in connection with this manuscript.

\section{References}

1. Charnley, J. Arthroplasty of the hip by the low friction technique. J Bone Joint Surg 43B, 601, 1961.

2. Tideman, H., and Lee, S. The TL modular endoprosthesis for mandibular reconstruction-a metallic yet biological approach. Asian J Oral Maxillofac Surg 18, 5, 2006.

3. Samman, N., Luk, W.K., Chow, T.W., Cheung, L.K., Tideman, H., and Clark, R.K. Custom-made titanium mandibular reconstruction tray. Aust Dent J 44, 195, 1999.

4. Cordeiro, P.G., Disa, J.J., Hidalgo, D.A., and Hu, Q.Y. Reconstruction of the mandible with osseous free flaps: a 10-year experience with 150 consecutive patients. Plast Reconstr Surg 104, 1314, 1999.

5. Goh, B.T., Lee, S., Tideman, H., and Stoelinga, P.J.W. Mandibular reconstruction: a review. Int J Oral Maxillofac Surg 37, 597, 2008.

6. Zimmermann, C.E., Börner, B.I., Hasse, A., and Sieg, P. Donor site morbidity after microvascular fibula transfer. Clin Oral Investig 5, 214, 2001.

7. Hidalgo, D.A., and Pusic, A.L. Free-flap mandibular reconstruction: a 10-year follow-up study. Plast Reconstr Surg 110, 438, 2002.

8. Warnke, P.H., Springer, I.N., Wiltfang, J., Acil, Y., Eufinger, H., Wehmoller, M., Russo, P.A., Bolte, H., Sherry, E., Behrens, E., and Terheyden, H. Growth and transplantation of a custom vascularised bone graft in a man. Lancet 364, 766, 2004.
9. Warnke, P.H., Wiltfang, J., Springer, I., Acil, Y., Bolte, H., Kosmahl, M., Russo, P.A., Sherry, E., Lutzen, U., Wolfart, S., and Terheyden, H. Man as living bioreactor: fate of an exogenously prepared customized tissue-engineered mandible. Biomaterials 27, 3163, 2006.

10. Mesimäki, K., Lindroos, B., Törnwall, J., Mauno, J., Lindqvist, C., Kontio, R., Miettinen, S., and Suuronen, R. Novel maxillary reconstruction with ectopic bone formation by GMP adipose stem cells. Int J Oral Maxillofac Surg 38, 201, 2009.

11. Malawer, M.M., and Chou, L.B. Prosthetic survival and clinical results with use of large-segment replacements in the treatment of high-grade bone sarcomas. J Bone Joint Surg Am 77, 1154, 1995.

12. Murray, D.W., Carr, A.J., and Bulstrode, C.J. Which primary total hip replacement? J Bone Joint Surg Br 77, 520, 1995.

13. Nafei, A., Kristensen, O., Knudsen, H.M., Hvid, I., and Jensen, J. Survivorship analysis of cemented total condylar knee arthroplasty. A long-term follow-up report on 348 cases. J Arthroplasty 11, 7, 1996.

14. Kuehn, K.D. Bone cements. Up-to-date comparison of physical and chemical properties of commercial materials. Heidelberg: Springer-Verlag, 2000, pp. 141-262.

15. Lewis, G. Properties of acrylic bone cement: state of the art review. J Biomed Mater Res 38, 155, 1997.

16. Lewis, G. Fatigue testing and performance of acrylic bonecement materials: state-of-the-art review. I Biomed Mater Res B Appl Biomater 66, 457, 2003.

17. Henrichsen, E., Jansen, K., and Krough-Poulsen, W. Experimental investigation of the tissue reaction to acrylic plastics. Acta Orthop Scand 22, 141, 1952.

18. Wiltse, L.L., Hall, R.H., and Stenehjem, J.C. Experimental studies regarding the possible use of self-curing acrylic in orthopaedic surgery. J Bone Joint Surg Am 39A, 961, 1957.

19. Freeman, M.A., Bradley, G.W., and Revell, P.A. Observations upon the interface between bone and polymethylmethacrylate cement. J Bone Joint Surg Br 64, 489, 1982.

20. DiPisa, J.A., Sih, G.S., and Berman, A.T. The temperature problem at the bone-acrylic cement interface of the total hip replacement. Clin Orthop Relat Res 121, 95, 1976.

21. Mjoberg, B., Pettersson, H., Rosenqvist, R., and Rydholm, A. Bone cement, thermal injury and the radiolucent zone. Acta Orthop Scand 55, 597, 1984.

22. Kindt-Larsen, T., Smith, D.B., and Jensen, J.S. Innovations in acrylic bone cement and application equipment. J Appl Biomater 6, 75, 1995.

23. Gilbert, J.L., Hasenwinkel, J.M., Wixson, R.L., and Lautenschlager, E.P. A theoretical and experimental analysis of polymerization shrinkage of bone cement: a potential major source of porosity. J Biomed Mater Res 52, 210, 2000.

24. Sundfeldt, M., Carlsson, L.V., Johansson, C.B., Thomsen, P., and Gretzer, C. Aseptic loosening, not only a question of wear: a review of different theories. Acta Orthop 77, 177, 2006.

25. Ries, M.D., Young, E., Al-Marashi, L., Goldstein, P., Hetherington, A., Petrie, T., and Pruitt, L. In vivo behavior of acrylic bone cement in total hip arthroplasty. Biomaterials 27, 256, 2006.

26. Buchholz, H.W., Elson, R.A., and Heinert, K. Antibioticloaded acrylic cement: current concepts. Clin Orthop Relat Res 190, 96, 1984.

27. Hanssen, A.D., and Rand, J.A. Evaluation and treatment of infection at the site of a total hip or knee arthroplasty. Instr Course Lect 48, 111, 1999. 
28. Levine, S.E., Esterhai, J.L., Jr., Heppenstall, R.B., Calhoun, J., and Mader, J.T. Diagnoses and staging. Osteomyelitis and prosthetic joint infections. Clin Orthop Relat Res 295, 77, 1993.

29. Costerton, J.W., Stewart, P.S., and Greenberg, E.P. Bacterial biofilms: a common cause of persistent infections. Science 284, 1318, 1999.

30. Gristina, A.G. Implant failure and the immuno-incompetent fibro-inflammatory zone. Clin Orthop Relat Res 298, 106, 1994.

31. Mah, T.F., and O'Toole, G.A. Mechanisms of biofilm resistance to antimicrobial agents. Trends Microbiol 9, 34, 2001.

32. Powers, K.A., Terpenning, M.S., Voice, R.A., and Kauffman, C.A. Prosthetic joint infections in the elderly. Am J Med 88, 9N, 1990.

33. Wang, C.J., Huang, T.W., Wang, J.W., and Chen, H.S. The often poor clinical outcome of infected total knee arthroplasty. J Arthroplasty 17, 608, 2002.

34. Kuehn, K.D., Ege, W., and Gopp, U. Acrylic bone cements: mechanical and physical properties. Orthop Clin North Am 36, 29, 2005.

35. Josefsson, G., Gudmundsson, G., Kolmert, L., and Wijkström, S. Prophylaxis with systemic antibiotics versus gentamicin bone cement in total hip arthroplasty. A five-year survey of 1688 hips. Clin Orthop Relat Res 253, 173, 1990.

36. Lynch, M., Esser, M.P., Shelley, P., and Wroblewski, B.M. Deep infection in Charnley low-friction arthroplasty. Comparison of plain and gentamicin-loaded cement. J Bone Joint Surg Br 69, 355, 1987.

37. Jiranek, W.A., Hanssen, A.D., and Greenwald, A.S. Antibiotic-loaded bone cement for infection prophylaxis in total joint replacement. J Bone Joint Surg Am 88, 2487, 2006.

38. Wahlig, H., and Dingeldein, E. Antibiotics and bone cements. Experimental and clinical long-term observations. Acta Orthop Scand 51, 49, 1980.

39. Webb, J.C., and Spencer, R.F. The role of polymethylmethacrylate bone cement in modern orthopaedic surgery. J Bone Joint Surg Br 89, 851, 2007.

40. Havelin, L.I., Espehaug, B., Wollser, S.E., and Engesaeter, L.B. Early aseptic loosening of uncemented femoral component in primary total hip replacement: a series based on the Norwegian Arthroplasty Register. J Bone Joint Surg 77B, 11, 1995.

41. Espehaug, B., Furnes, O., Havelin, L.I., Engesaeter, L.B., and Vollset, S.E. The type of cement and failure of total hip replacements. J Bone Joint Surg Br 84, 832, 2002.

42. Jasty, M., Maloney, W.J., Bragdon, C.R., O'Connor, D.O., Haire, T., and Harris, W.H. The initiation of failure in cemented femoral components of hip arthroplasties. J Bone Joint Surg Br 73, 551, 1991.

43. Savarino, L., Stea, S., Ciapetti, G., Paganetto, G., Donati, M.E., Alvergna, P., and Pizzoferrato, A. Microstructural investigation of bone-cement interface. I Biomed Mater Res 29, 701, 1995.

44. Bettencourt, A., Calado, A., Amaral, J., Alfaia, A., Vale, F.M., Monteiro, J., Montemor, M.F., Ferreira, M.G., and Castro, M. Surface studies on acrylic bone cement. Int J Pharm 278, 181, 2004.

45. Lewis, G. Alternative acrylic bone cement formulations for cemented arthroplasties: present status, key issues, and future prospects. J Biomed Mater Res B Appl Biomater 84, 301, 2008.
46. Kuehn, K.D., Ege, W., and Gopp, U. Acrylic bone cements: composition and properties. Orthop Clin North Am 36, 17, 2005.

47. Deb, S. A review of improvements in acrylic bone cements. J Biomater Appl 14, 16, 1999.

48. Deb, S., and Vazquez, B. The effect of cross-linking agents on acrylic bone cements containing radiopacifiers. Biomaterials 22, 2177, 2001.

49. Nien, Y.-H., and Chen, J. Studies of the mechanical and thermal properties of cross-linked poly(methylmethacrylateacrylic acid-allylmethacrylate)-modified bone cement. J Appl Polym Sci 100, 3727, 2006.

50. Pascual, B., Gurruchaga, M., Ginebra, M.P., Gil, F.J., Planell, J.A., and Goñi, I. Influence of the modification of P/L ratio on a new formulation of acrylic bone cement. Biomaterials 20, 465, 1999.

51. Sakai, T., Morita, S., Shinomiya, K.-I., Watanabe, A., Nakabayashi, N., and Ishihara, K. In vivo evaluation of the bond strength of adhesive 4-META/MMA-TBB bone cement under weightbearing conditions. I Biomed Mater Res A 52, 128, 2000.

52. G Gureck, U., Grübel, S., Thull, R., and Barralet, J.E. Modified PMMA cements for a hydrolysis resistant metal-polymer interface in orthopaedic applications. Acta Biomater 1, 671, 2005.

53. Jager, M., and Wilke, A. Comprehensive biocompatibility testing of a new PMMA-HA bone cement versus conventional PMMA cement in vitro. J Biomater Sci Polym Ed 14, 1283, 2003.

54. Shinzato, S., Nakamura, T., Kokubo, T., and Kitamura, Y. A new bioactive bone cement: effect of glass bead filler content on mechanical and biological properties. J Biomed Mater Res 54, 491, 2001.

55. Goodwin, C.J., Braden, M., Downes, S., and Marshall, N.J. Investigation into the release of bioactive recombinant human growth hormone from normal and low-viscosity poly(methylmethacrylate) bone cements. J Biomed Mater Res A 34, 47, 1997.

56. Kim, S.B., Kim, Y.J., Yoon, T.L., Park, S.A., Cho, I.H., Kim, E.J., Kim, I.A., and Shin, J.W. The characteristics of a hydroxyapatite-chitosan-PMMA bone cement. Biomaterials 25, 5715, 2004.

57. Kawanabe, K., Tamura, J., Yamamuro, T., Nakamura, T., Kokubo, T., and Yoshihara, S. A new bioactive bone cement consisting of BIS-GMA resin and bioactive glass powder. J Appl Biomater 4, 135, 1993.

58. Deb, S., Braden, M., and Bonfield, W. Water absorption characteristics of modified hydroxyapatite bone cements. Biomaterials 16, 1095, 1995.

59. Lee, R.R., Ogiso, M., Watanabe, A., and Ishihara, K. Examination of hydroxyapatite filled 4-META/MMA-TBB adhesive bone cement in in vitro and in vivo environment. J Biomed Mater Res 38, 11, 1997.

60. Islas-Blancas, M.E., Cervantes-Uc, J.M., Vargas-Coronado, R., Cauich-Rodríguez, J.V., Vera-Graziano, R., and MartinezRicha, A. Characterization of bone cements prepared with functionalized methacrylates and hydroxyapatite. J Biomater Sci Polym Ed 12, 893, 2001.

61. Salih, V., Mordan, N., Neel, E.A.B., Armitage, D.A., Jones, F.H., Knowles, J.C., Nazhat, S.N., Vargas-Coronado, R., and Cauich-Rodriguez, J.V. Surface characterization of various bone cements prepared with functionalised methacrylates/bioactive ceramics in relation to $\mathrm{HOB}$ behaviour. Acta Biomater 2, 143, 2006. 
62. Miyazaki, T., Ohtsuki, C., Kyomoto, M., Tanihara, M., Mori, A., and Kuramoto, K. Bioactive PMMA bone cement prepared by modification with methacryloxypropyltrimethoxysilane and calcium chloride. J Biomed Mater Res A 67, 1417, 2003.

63. Ohtsuki, C., Miyazaki, T., Kyomoto, M., Tanihara, M., and Osaka, A. Development of bioactive PMMA-based cement by modification with alkoxysilane and calcium salt. $\underline{\text { Mater }}$ Sci Mater Med 12, 895, 2001.

64. Nguyen, S., and Marchessault, R.H. Synthesis and properties of graft copolymers based on poly(3-hydroxybutyrate) macromonomers. Macromol Biosci 4, 262, 2004.

65. Nguyen, S. Graft copolymers of methyl methacrylate and poly([R]-3-hydroxybutyrate) macromonomers for acrylic bone cement formulations: compression testing. J Biomed Mater Res B Appl Biomater 77, 5, 2006.

66. Liu, Y.K., Park, J.B., Njus, G.O., and Stienstra, D. Bone particle impregnated bone cement: an in vitro study. J Biomed Mater Res 21, 247, 1987.

67. Vazquez, B., Ginebra, M.P., Gil, X., Planell, J.A., and San Roman, J. Acrylic bone cements modified with $\beta$-TCP particles encapsulated with poly(ethylene glycol). Biomaterials 26, 4309, 2005.

68. Minari, C., Baleani, M., Cristofolini, L., and Baruffaldi, F. The effect on the fatigue strength of bone cement of adding sodium fluoride. Proc Inst Mech Eng [H] 215, 251, 2001.

69. Canul-Chuil, A., Vargas-Coronado, R., Cauich-Rodriguez, J.V., Martinez-Richa, A., Fernandez, E., and Nazhat, S.N. Comparative study of bone cements prepared with either HA or $\alpha$-TCP and functionalized methacrylates. $\underline{\text { Biomed }}$ Mater Res B Appl Biomater. 64, 27, 2003.

70. Lin, L.C., Chang, S.J., Kuo, S.M., Chen, S.F., and Kuo, C.H. Evaluation of chitosan/b-tricalcium phosphate microspheres as a constituent to PMMA cement. J Mater Sci Mater Med 16, 567, 2005.

71. Yang, J.M., Shih, C.H., Chang, C.-N., Lin, F.H., Jiang, J.M., Hsu, Y.G., Su, W.Y., and See, L.C. Preparation of epoxy$\mathrm{SiO} 2$ hybrid solgel material for bone cement. J Biomed Mater Res A 64, 138, 2003.

72. Goto, K., Tamura, J., Shinzato, S., Fujibayashi, S., Hashimoto, M., Kawashita, M., Kokubo, T., and Nakamura, T. Bioactive bone cements containing nano-sized titania particles for use as bone substitutes. Biomaterials 26, 6496, 2005.

73. Cervantes-Uc, J.M., Vázquez-Torres, H., Cauich-Rodríguez, J.V., Vázquez-Lasa, B., and del Barrio, J.S. Comparative study on the properties of acrylic bone cements prepared with either aliphatic or aromatic functionalized methacrylates. Biomaterials 26, 4063, 2005.

74. Weightman, B., Freeman, M.A.R., Revell, P.A., Braden, M., Albrektsson, B.E.J., and Carlson, L.V. The mechanical properties of cement and loosening of the femoral component of hip replacements. J Bone Joint Surg 69, 558, 1987.

75. Pilliar, R.M. Carbon reinforced acrylic cement. Orthop Rev 9, 67, 1980.

76. Kotha, S.P., Li, C., Schimd, S.R., and Mason, J.J. Fracture toughness of steel-fiber-reinforced bone cement. $\underline{\mathrm{J} \text { Biomed }}$ Mater Res A 70, 514, 2004.

77. Kotha, S.P., Li, C., McGinn, P., Schmid, S.R., and Mason, J.J. Improved mechanical properties of acrylic bone cement with short titanium fiber reinforcement. J Mater Sci Mater Med 17, 743, 2006.

78. Pourdeyhimi, B., Robinson, H.H., IV, Schwartz, P., and Wagner, H.D. Fracture toughness of Kevlar 29/poly(methyl methacrylate) composite materials for surgical implantations. Ann Biomed Eng 14, 277, 1986.

79. Khang, G., Bang, Y.H., Park, J.B., and Lee, H.B. Improved bonding strength of polyethylene/poly(methyimethacrylate) bone cement-a preliminary study. Biomed Mater Eng 6, 335, 1996.

80. Yang, J.M., Huang, P.Y., Yang, M.C., and Sing, K.L. Effect of MMAg-UHMWPE grafted fibre on mechanical properties of acrylic bone cement. J Biomed Mater Res 38, 361, 1997.

81. Murikami, A., Behiri, J.C., and Bonfield, W. Rubbermodified bone cement. J Mater Sci 23, 2029, 1988.

82. Kennedy, J.P., Askew, M.J., and Richard, G.C. Polyisobutylene-toughened poly(methyl methacrylate): III. PMMA-1-PIB networks as bone cements. J Biomater Sci Polym Ed 4, 445, 1993.

83. Vila, M.M., Ginebra, M.P., Gil, F.J., and Planell, J.A. Effect of porosity and environment on the mechanical behavior of acrylic bone cement modified with acrylonitrilebutadiene-styrene particles. I. Fracture toughness. J Biomed Mater Res 48, 121, 1999.

84. Abraham, G.A., Vallo, C.I., Roman, J.S., and Cuadrado, T.R. Mechanical characterization of self-curing acrylic cements formulated with poly(methylmethacrylate)/poly (e-caprolactone) beads. J Biomed Mater Res B 70, 340, 2004.

85. Shinzato, S., Nakamura, T., Kokubo, T., and Kitamura, Y. Composites consisting of poly(methyl methacrylate) and alumina powder: an evaluation of their mechanical and biological properties. J Biomed Mater Res 60, 585, 2002.

86. Shi, Z., Neoh, K.G., Kang, E.T., and Wang, W. Antibacterial and mechanical properties of bone cement impregnated with chitosan nanoparticles. Biomaterials 27, 2440, 2006.

87. Marrs, B., Andrews, R., Rantell, T., and Pienkowski, D. Augmentation of acrylic bone cement with multiwall carbon nanotubes. J Biomed Mater Res A 77, 269, 2006.

88. Madigan, S., Towler, M.R., and Lewis, G. Optimisation of the composition of an acrylic bone cement: application to relative amounts of the initiator and the activator/co-initiator in surgical simplex P. J Mater Sci Mater Med 17, 307, 2006.

89. Hasenwinkel, J.M., Lautenschlager, E.P., Wixson, R.L., and Gilbert, J.L. A novel high viscosity, two-solution acrylic bone cement: effect of chemical composition on properties. J Biomed Mater Res 47, 36, 1999.

90. Méndez, J.A., Aguilar, M.R., Abraham, G.A., Vázquez, B., Dalby, M., Di Silvio, L., and San Román, J. New acrylic bone cements conjugated to vitamin E: curing parameters, properties, and biocompatibility. I Biomed Mater Res 62, 299, 2002.

91. Tanzi, M.C., Sket, I., Gatti, A.M., and Monari, E. Physical characterization of acrylic bone cement cured with new accelerator systems. Clin Mater 8, 131, 1991.

92. Deb, S., Lewis, G., Janna, S.W., Vazquez, B., and San Roman, J. Fatigue and fracture toughness of acrylic bone cements modified with long-chain amine activators. J Biomed Mater Res A 67, 571, 2003.

93. van Hooy-Corstjens, C.S., Govaert, L.E., Spoelstra, A.B., Bulstra, S.K., Wetzels, G.M., and Koole, L.H. Mechanical behaviour of a new acrylic radiopaque iodine-containing bone cement. Biomaterials 25, 2657, 2004.

94. Hernandez, L., Vazquez, B., Lopez-Bravo, A., Parra, J., Goni, I., and Gurruchaga, M. Acrylic bone cements with bismuth salicylate: behavior in simulated physiological conditions. J Biomed Mater Res A 80, 321, 2007.

95. Persson, C., Guandalini, L., Baruffaldi, F., Peirotti, L., and Baleani, M. Radiopacity of tantalum-loaded acrylic bone cement. Proc Inst Mech Eng [H] 220, 787, 2006. 
96. Xu, H., Abdulghani, S., Behiri, J., and Sabokbar, A. Osteolytic potential of triphenyl bismuth as an alternative contrast medium in acrylic bone cement. J Biomed Mater Res Part B 75, 64, 2005.

97. Takechi, M., Miyamoto, Y., Ishikawa, K., Toh, T., Yuasa, T., Nagayama, M., and Suzuki, K. Initial histological evaluation of anti-washout type fast-setting calcium phosphate cement following subcutaneous implantation. Biomaterials 19, 2057, 1998.

98. Ishikawa, K. Calcium phosphate cement. In: Kokubo, T., ed. Bioceramics and Their Application. Boca Raton, FL: CRC Press, 2008, pp. 438-463.

99. Brown, W.E., and Chow, L.C. Dental restorative cement pastes. U.S. Pat No. 4. 518, 430, 1988.

100. Gierse, H., and Donath, K. Reactions and complications after the implantation of Endobon including morphological examination of explants. Arch Orthop Trauma Surg 119, 349, 1999.

101. Rabalais, M.L., Yukna, R.A., and Mayer, E.T. Evaluation of durapatite ceramic as an alloplastic implant in periodontal osseous defects: initial six-month results. J Periodontol 52, 680, 1981.

102. Block, M.S., and Kent, J.N. Long term evaluation of hydroxylapatite augmentation of deficient mandibular alveolar ridges. J Oral Maxillofac Surg 42, 793, 1984.

103. Kent, J.N., Zide, M.F., Kay, J.F., and Jarcho, M. Hydroxylapatite blocks and particles as bone graft substitutes in orthognathic and reconstructive surgery. I Oral Maxillofac Surg 44, 597, 1986.

104. Zide, M.F., Kent, J.N., and Machado, L. Hydroxylapatite cranioplasty directly over dura. J Oral Maxillofac Surg 45, 481, 1987.

105. Weiss, D.D., Sachs, M.A., and Woodard, C.R. Calcium phosphate bone cements: a comprehensive review. J Long Term Eff Med Implants 13, 41, 2003.

106. Stankewich, C.J., Swiontkowski, M.F., Tencer, A.F., Yetkinler, D.N., and Poser, R.D. Augmentation of femoral neck fracture fixation with an injectable calcium-phosphate bone mineral cement. J Orthop Res 14, 786, 1996.

107. Goodman, S.B., Bauer, T.W., Carter, D., Casteleyn, P.P., Goldstein, S.A., Kyle, R.F., Larsson, S., Stankewich, C.J., Swiontkowski, M.F., Tencer, A.F., Yetkinler, D.N., and Poser, R.D. Norian SRS cement augmentation in hip fracture treatment. Laboratory and initial clinical results. Clin Orthop Relat Res 348, 42, 1998.

108. Ooms, E.M., Wolke, J.G., van der Waerden, J.P., and Jansen, J.A. Use of injectable calcium-phosphate cement for the fixation of titanium implants: an experimental study in goats. J Biomed Mater Res B Appl Biomater 66, 447,2003.

109. Link, D.P., van den Dolder, J., van den Beucken, J.J., Wolke, J.G., Mikos, A.G., and Jansen, J.A. Bone response and mechanical strength of rabbit femoral defects filled with injectable CaP cements containing TGF-beta 1 loaded gelatin microparticles. Biomaterials 29, 675, 2008.

110. Xu, H.H., Quinn, J.B., Takagi, S., Chow, L.C., and Eichmiller, F.C. Strong and macroporous calcium phosphate cement: effects of porosity and fiber reinforcement on mechanical properties. J Biomed Mater Res 57, 457, 2001.

111. Fujibayashi, S., Senaha, Y., Yoshihara, S., Tamura, J., and Nakamura, T. Long-term follow-up study of bioactive bone cement for repairing a segmental defect in a canine femur. J Long Term Eff Med Implants 11, 93, 2001.

112. Ginebra, M.P., Traykova, T., and Planell, J.A. Calcium phosphate cements as bone drug delivery systems: a review. J Control Release 113, 102, 2006.
113. Habraken, W.J.E.M., Wolke, J.G.C., and Jansen, J.A. Ceramic composites as matrices and scaffolds for drug delivery in tissue engineering. Adv Drug Deliv Rev 59, 234, 2007.

114. Wilson, C.E., Brujin, J.D., van Blitterswijk, C.A., Verbout, A.J., and Dhert, W.J. Design and fabrication of standardized hydroxyapatite scaffolds with a defined macro-architecture by rapid prototyping for bone tissue-engineering research. J Biomed Mater Res A 68, 123, 2004.

115. Yang, H., Yang, S., Chi, X., and Evans, J.R. Fine ceramic lattices prepared by extrusion freeforming. J Biomed Mater Res B 79, 116, 2006.

116. Peltier, L.F. The use of plaster of Paris to fill defects in bone. Clin Orthop 21, 1, 1961.

117. Turner, T.M., Urban, R.M., Gitelis, S., Haggard, W.O., and Richelsoph, K. Resorption evaluation of a large bolus of calcium sulfate in a canine medullary defect. Orthopedics 26(Suppl 5), 577, 2003.

118. Kelly, C.M., and Wilkins, R.M. Treatment of benign bone lesions with an injectable calcium sulfate-based bone graft substitute. Orthopedics 27(Suppl 1), 131, 2004.

119. Tay, B.K., Patel, V.V., and Bradford, D.S. Calcium sulfateand calcium phosphate-based bone substitutes. Mimicry of the mineral phase of bone. Orthop Clin North Am 30, 615, 1999.

120. Huff, W., and Grisoni, B. Mechanical integrity of rate bone after autograft and calcium sulfate graft. Proceedings of the Fifth World Biomaterials Congress, Toronto, May 29June 2, 1996.

121. Thomas, M.V., and Puleo, D.A. Calcium sulfate: properties and clinical applications. J Biomed Mater Res B 88, 597, 2009.

122. Carroll, M., Lewis, G., Xu, J., Moseley, J., Cole, J., and Haggard, W. Evaluation of a synthetic bone defect test model to aid in the selection of materials for use in vertebral body compression fracture repair. Orthopedics 27(Suppl 1), 119, 2004.

123. Brook, I.M., and Hatton, P.V. Glass-ionomers: bioactive implant materials. Biomaterials 19, 565, 1998.

124. Hatton, P.V., Hurrell-Gillingham, K., and Brook, I.M. Biocompatibility of glass-ionomer bone cements. L Dent 34, 598, 2006.

125. Loescher, A.R., Robinson, P.P., and Brook, I.M. The effects of implanted ionomeric and acrylic bone cements on peripheral nerve function. J Mater Sci Med 5, 108, 1994.

126. Loescher, A.R., Robinson, P.P., and Brook, I.M. The immediate effects of ionomeric and acrylic bone cements on peripheral nerve function. I Mater Sci Med 5, 551, 1994.

127. Reusche, E., Rohwer, J., Forth, W., Helms, J., and Geyer, G. Ionomeric cement and aluminium encephalopathy. Lancet 345, 1633, 1995.

128. Granström, G., Holmquist, J., and Tjellström, A. Facial nerve paralysis following repair of the external ear canal with ionomeric cement. Ear Nose Throat J 79, 495, 2000.

129. Mount, G.J., Makinson, O.F., and Peters, M.C. The strength of auto-cured and light-cured materials. The shear punch test. Aust Dent J 41, 118, 1996.

130. Yap, A.U., Pek, Y.S., Kumar, R.A., Cheang, P., and Khor, K.A. Experimental studies on a new bioactive material: HAIonomer cements. Biomaterials 23, 955, 2002.

131. Knock, F., Glenn, J. Dental material and method. United States patent 2,588,139, 26 June, 1951.

132. Bowen, R.L. Properties of a silica-reinforced polymer for dental restorations. J Am Dent Assoc 66, 57, 1963.

133. Wintermantel, E., Mayer, J., and Goehring, T.N. Composites for biomedical applications. In: Buschow, K.H.J., 
Cahn, R.W., Flemings, M.C., Ilschner, B., Kramer, E.J., and Mahajan, S., eds. Encyclopedia of Materials: Science and Technology. Oxford, UK: Elsevier, 2001, pp. 1371-1376.

134. Kawagoe, K., Saito, M., Shibuya, T., Nakashima, T., Hino, $\mathrm{K}$., and Yoshikawa, H. Augmentation of cancellous screw fixation with hydroxyapatite composite resin (CAP) in vivo. J Biomed Mater Res 53, 678, 2000.

135. Saito, M., Maruoka, A., Mori, T., Sugano, N., and Hino, K. Experimental studies on a new bioactive bone cement: hydroxyapatite composite resin. Biomaterials 15, 156, 1994.

136. Yamamuro, T., Nakamura, T., Iida, H., Kawanabe, K., Matsuda, Y., Ido, K., Tamura, J., and Senaha, Y. Development of bioactive bone cement and its clinical applications. Biomaterials 19, 1479, 1998.

137. Zhao, F., Lu, W.W., Luk, K.D., Cheung, K.M., Wong, C.T., Leong, J.C., and Yao, K.D. Surface treatment of injectable strontium-containing bioactive bone cement for vertebroplasty. I Biomed Mater Res B Appl Biomater 69, 79, 2004.

138. Olea, N., Pulgar, R., Pérez, P., Olea-Serrano, F., Rivas, A., Novillo-Fertrell, A., Pedraza, V., Soto, A.M., and Sonnenschein, C. Estrogenicity of resin-based composites and sealants used in dentistry. Environ Health Perspect 104,298, 1996.

139. Soderholm, K.J., and Mariotti, A. BIS-GMA-based resins in dentistry: are they safe? J Am Dent Assoc 130, 201, 1999.

140. Geurtsen, W. Biocompatibility of resin-modified filling materials. Crit Rev Oral Biol Med 11, 333, 2000.

141. Shajii, L., and Santerre, J.P. Effect of filler content on the profile of released biodegradation products in micro-filled bis-GMA/TEGDMA dental composite resins. Biomaterials 20, 1897, 1999.

142. Jones, L.C., and Hungerford, D.S. Cement disease. Clin Orthop Relat Res 225, 192, 1987.

143. Maloney, W.J., Jasty, M., Rosenberg, A., and Harris, W.H. Bone lysis in well-fixed cemented femoral components. J Bone Joint Surg Br 72, 966, 1990.

144. Zicat, B., Engh, C.A., and Gokcen, E. Patterns of osteolysis around total hip components inserted with and without cement. J Bone Joint Surg Am 77, 432, 1995.

145. Sinha, R.K., Dungy, D.S., and Yeon, H.B. Primary total hip arthroplasty with a proximally porous-coated femoral stem. J Bone Joint Surg Am 86A, 1254, 2004.

146. Dumbleton, J., and Manley, M.T. Hydroxyapatite-coated prostheses in total hip and knee arthroplasty. J Bone Joint Surg Am 86A, 2526, 2004.

147. Shepperd, J.A., and Apthorp, H. A contemporary snapshot of the use of hydroxyapatite coating in orthopaedic surgery. J Bone Joint Surg Br 87, 1046, 2005.

148. Rahbek, O., Kold, S., Bendix, K., Overgaard, S., and Søballe, K. Superior sealing effect of hydroxyapatite in porouscoated implants: experimental studies on the migration of polyethylene particles around stable and unstable implants in dogs. Acta Orthop 76, 375, 2005.

149. Overgaard, S., Lind, M., Glerup, H., Bünger, C., and Søballe, K. Porous-coated versus grit-blasted surface texture of hydroxyapatite-coated implants during controlled micromotion: mechanical and histomorphometric results. J Arthroplasty 13, 449, 1998.

150. Morshed, S., Bozic, K.J., Ries, M.D., Malchau, H., and Colford, J.M., Jr. Comparison of cemented and uncemented fixation in total hip replacement: a meta-analysis. Acta Orthop 78, 315, 2007.
151. Carlsson, A., Björkman, A., Besjakov, J., and Onsten, I. Cemented tibial component fixation performs better than cementless fixation: a randomized radiostereometric study comparing porous-coated, hydroxyapatite-coated and cemented tibial components over 5 years. Acta Orthop 76, 362, 2005.

152. Nilsson, K.G., Kärrholm, J., Carlsson, L., and Dalén, T. Hydroxyapatite coating versus cemented fixation of the tibial component in total knee arthroplasty: prospective randomized comparison of hydroxyapatite-coated and cemented tibial components with 5-year follow-up using radiostereometry. J Arthroplasty 14, 9, 1999.

153. Bodde, E.W., Cammaert, C.T., Wolke, J.G., Spauwen, P.H., and Jansen, J.A. Investigation as to the osteoinductivity of macroporous calcium phosphate cement in goats. J Biomed Mater Res B Appl Biomater 83, 161, 2007.

154. Yuan, H., Yang, Z., Li, Y., Zhang, X., De Bruijn, J.D., and De Groot, K. Osteoinduction by calcium phosphate biomaterials. J Mater Sci Mater Med 9, 723, 1998.

155. Zaffe, D. Some considerations on biomaterials and bone. Micron 36, 583, 2005.

156. Gosain, A.K., Song, L., Riordan, P., Amarante, M.T., Nagy, P.G., Wilson, C.R., Toth, J.M., and Ricci, J.L. A 1-year study of osteoinduction in hydroxyapatite-derived biomaterials in an adult sheep model. Part I. Plast Reconstr Surg 109, 619, 2002.

157. Yuan, H., Li, Y., de Bruijn, J.D., de Groot, K., and Zhang, X. Tissue responses of calcium phosphate cement: a study in dogs. Biomaterials 21, 1283, 2000.

158. Maus, U., Andereya, S., Gravius, S., Ohnsorge, J.A., Niedhart, C., and Siebert, C.H. BMP-2 incorporated in a tricalcium phosphate bone substitute enhances bone remodeling in sheep. J Biomater Appl 22, 559, 2008.

159. Fei, Z., Hu, Y., Wu, D., Wu, H., Lu, R., Bai, J., and Song, H. Preparation and property of a novel bone graft composite consisting of rhBMP-2 loaded PLGA microspheres and calcium phosphate cement. J Mater Sci Mater Med 19, 1109, 2008.

160. Kroese-Deutman, H.C., Ruhé, P.Q., Spauwen, P.H., and Jansen, J.A. Bone inductive properties of rhBMP-2 loaded porous calcium phosphate cement implants inserted at an ectopic site in rabbits. Biomaterials 26, 1131, 2005.

161. Ruhé, P.Q., Kroese-Deutman, H.C., Wolke, J.G., Spauwen, P.H., and Jansen, J.A. Bone inductive properties of rhBMP-2 loaded porous calcium phosphate cement implants in cranial defects in rabbits. Biomaterials 25, 2123, 2004.

Address correspondence to: Kok Weng Lye, B.D.S., M.D.S. Department of Oral and Maxillofacial Surgery National Dental Centre

5, Second Hospital Ave. Singapore 168938 Singapore

E-mail: kokwenglye@yahoo.com

Received: March 1, 2009

Accepted: August 10, 2009

Online Publication Date: September 30, 2009 


\section{This article has been cited by:}

1. S. M. Barinov, V. S. Komlev. 2011. Calcium phosphate bone cements. Inorganic Materials 47:13, 1470-1485. [CrossRef]

2. Kok Weng Lye, Henk Tideman, Joop C. G. Wolke, Matthias A. W. Merkx, Francis K. C. Chin, John A. Jansen. 2011. Biocompatibility and bone formation with porous modified PMMA in normal and irradiated mandibular tissue. Clinical Oral Implants Research n/a-n/a. [CrossRef]

3. M.-S. Scholz, J.P. Blanchfield, L.D. Bloom, B.H. Coburn, M. Elkington, J.D. Fuller, M.E. Gilbert, S.A. Muflahi, M.F. Pernice, S.I. Rae, J.A. Trevarthen, S.C. White, P.M. Weaver, I.P. Bond. 2011. The use of composite materials in modern orthopaedic medicine and prosthetic devices: A review. Composites Science and Technology . [CrossRef]

4. James D. Kretlow, Meng Shi, Simon Young, Patrick P. Spicer, Nagi Demian, John A. Jansen, Mark E. Wong, F. Kurtis Kasper , Antonios G. Mikos . 2010. Evaluation of Soft Tissue Coverage over Porous Polymethylmethacrylate Space Maintainers Within Nonhealing Alveolar Bone Defects. Tissue Engineering Part C: Methods 16:6, 1427-1438. [Abstract] [Full Text HTML] [Full Text PDF] [Full Text PDF with Links]

5. Sun-Kyung Lee, Sang-Kwang Lee, Sang-Im Lee, Jeong-Hui Park, Jun-Hyeog Jang, Hae-Won Kim, Eun-Cheol Kim. 2010. Effect of Calcium Phosphate Cements on Growth and Odontoblastic Differentiation in Human Dental Pulp Cells. Journal of Endodontics 36:9, 1537-1542. [CrossRef] 